\title{
Hypothalamic control of gonadotrophin and prolactin secretion in pigs
}

\author{
R. R. Kraeling and C. R. Barb \\ Animal Physiology Research Unit, USDA-ARS, Russell Research Center, P.O. Box 5677, Athens, \\ Georgia 30602, USA
}

Keywords: hypothalamus; gonadotrophin; prolactin; pig; neuroendocrine

\section{Introduction}

Interoceptive and exteroceptive stimuli detected by the central nervous system (CNS) are translated by the neuroendocrine system into signals which alter pituitary gland hormone function as depicted in Fig. 1 for gonadotrophin and prolactin secretion. The organization of this system has been thoroughly reviewed by Page (1988). Table 1 illustrates that components of the neuroendocrineovarian axis of the pig are functional before the onset of puberty at approximately 210 days of age and before the onset of oestrus that occurs 4-7 days after weaning. Post-partum sows in a state of prolonged anoestrus also respond to appropriate stimuli. Mechanisms which bring these components into the proper temporal relationships to generate oestrous cycles beginning at puberty and after weaning in sows reside in the CNS.

The pattern of luteinizing hormone (LH) secretion, reflected by frequency, amplitude and duration of episodic release, is an important regulator of follicle development and ovulation in the primate, rat and sheep (Greenwald \& Terranova, 1988). It is well established, at least in rats, that the pulsatile secretion of LH is controlled by a "pulse generator" of the hypothalamus and the preovulatory LH surge by a "surge generator" of the hypothalamus (Weiner et al., 1988). These patterns of LH secretion presumably reflect the pattern of gonadotrophin-releasing hormone $(\mathrm{GnRH})$ released by neurosecretory neurones into the hypothalamo-hypophysial portal blood system (Goodman, 1988). Gonadal steroids and signals from other neurones modulate the frequency and amplitude of GnRH release. Prolactin secretion is also controlled by hypothalamic factors such as dopamine and thyroid-stimulating hormone-releasing hormone (TRH).

This review will present evidence for control of gonadotrophin secretion by hypothalamic pulse and surge generators, and the role of ovarian steroids, various neurotransmitters and the endogenous opioid peptides (EOP; neural peptides with morphine-like biological activity) in modulating gonadotrophin and prolactin secretion during various physiological states in the pig.

\section{Gonadotrophin 'pulse generator'}

We determined, through frequent blood sampling, that onset of puberty was immediately preceded by a significant increase in serum LH concentrations characterized by an accelerated frequency (approximately 1 peak/h) of lower amplitude LH pulses compared to previous ages (Lutz et al., 1984). As in the prepubertal period, secretion of follicle-stimulating hormone (FSH) and $\mathrm{LH}$ is suppressed during lactation in sows, but secretion of both gonadotrophins gradually increases as lactation progresses (Edwards, 1982; Britt et al., 1985; Cox \& Britt, 1986; Foxcroft et al., 1987). Weaning results in an immediate and dramatic increase in both basal and pulsatile LH secretion, but reports of the effects of weaning on FSH secretion are equivocal (Edwards, 1982; Britt $e t$ al., 1985; Shaw \& Foxcroft, 1985; Cox \& Britt, 1986; Foxcroft et al., 1987; Barb et al., 1987). 


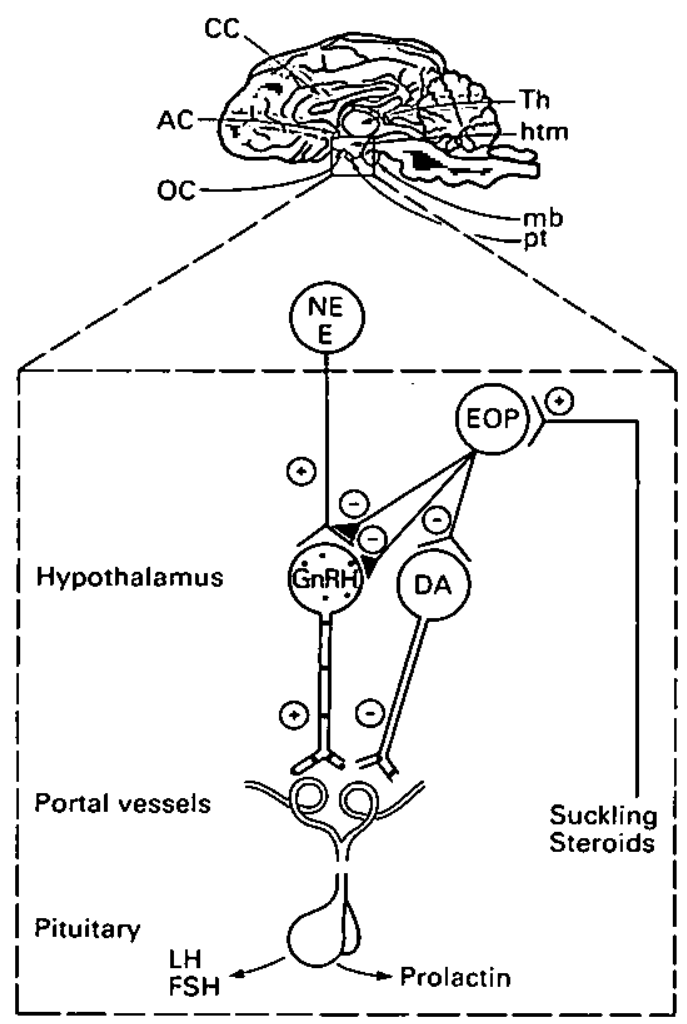

Fig. 1. The neuroendocrine system of the pig with proposed neuronal network regulating LH, FSH and prolactin secretion. The box represents the hypothalamus (htm)-pituitary gland (pt) unit. $\mathrm{AC}=$ anterior commissure, $\mathrm{CC}=$ corpus callosum, $\mathrm{DA}=$ dopamine, $\mathrm{E}=$ epinephrine, EOP = endogenous opioid peptide, $\mathrm{GnRH}=$ gonadotrophin releasing hormone, $\mathrm{mb}=$ mamillary body, $\mathrm{NE}=$ norepinephrine, $\mathrm{OC}=$ optic chiasma, $\mathrm{Th}=$ thalamus.

Table 1. Chronology of the neuroendocrine-ovarian axis in the female pig

\begin{tabular}{|c|c|c|c|}
\hline Component & $\begin{array}{l}\text { Days after } \\
\text { birth* }\end{array}$ & $\begin{array}{l}\text { Lactating sow } \uparrow \\
\text { (days) }\end{array}$ & $\begin{array}{c}\text { Anoestrous } \\
\text { sow }>30 \text { days } \\
\text { after weaning } \\
(+=\text { positive })\end{array}$ \\
\hline $\begin{array}{l}\text { Pituitary response to } \\
\text { GnRH }\end{array}$ & $\begin{array}{l}6-10 \\
\text { (Elsaesser, 1982; } \\
\text { Colenbrander el al., 1987) }\end{array}$ & $\begin{array}{l}10 \\
\text { (Britt et al., 1985) }\end{array}$ & $\stackrel{+}{\text { (Britt et al., 1985) }}$ \\
\hline $\begin{array}{l}\text { Brain-pituitary response } \\
\text { to ovariectomy }\end{array}$ & $\begin{array}{l}60 \\
\text { (Foxcroft et al., 1984) }\end{array}$ & $\begin{array}{l}2-4 \\
\text { (Britt et al., 1985) }\end{array}$ & Not reported \\
\hline $\begin{array}{l}\text { Brain-pituitary response } \\
\text { to oestradiol }\end{array}$ & $\begin{array}{l}60 \\
\text { (Elsaesser, 1982; } \\
\text { Foxcroft et al., 1984) }\end{array}$ & $\begin{array}{l}28 \\
\text { (Britt et al., 1985; } \\
\text { Cox et al., 1988) }\end{array}$ & $\stackrel{+}{\text { (Britt et al., 1985) }}$ \\
\hline $\begin{array}{l}\text { Ovarian response to } \\
\text { gonadotrophins }\end{array}$ & $\begin{array}{l}100 \\
\text { (Casida, 1976) }\end{array}$ & $\begin{array}{l}\text { I-5 } \\
\text { (Kirkpatrick el al., 1965; } \\
\text { Britt et al., 1985) }\end{array}$ & $\stackrel{+}{(\text { Britl el al. . 1985, 1986) }}$ \\
\hline
\end{tabular}

*Onset of puberty expected at $\sim 210$ days of age.

†Oestrus expected 4-7 days after weaning. 
As has been established for sheep and primates, pulsatile LH secretion in pigs probably results from pulsatile secretion of GnRH from the hypothalamus. Oestrus and ovulation were induced by pulsatile i.v. injections of $1 \mu \mathrm{g} \mathrm{GnRH/h}$ in intact prepubertal gilts (Lutz ef al., 1985) and prepubertal gilts with transection of the hypophysial stalk and injected with PMSG (Kraeling et al., 1987). Oestrus and ovulation were induced in lactating sows by pulsatile i.v. injections of $2.5 \mu \mathrm{g} \mathrm{GnRH} / 2 \mathrm{~h}$ or $1.5 \mu \mathrm{g} \mathrm{GnRH} / \mathrm{h}$ (Cox \& Britt, 1982; Armstrong et al., 1987) as well as in sows in a state of prolonged post-partum anoestrus by pulsatile i.v. injections of $1.5 \mu \mathrm{g} \mathrm{GnRH/h}$ (Britt et al., 1985).

Pulsatile secretion of $\mathrm{LH}$ was abolished by hypophysial stalk transection (Carpenter \& Anderson, 1985; Kraeling et al., 1986; Kesner et al., 1989a) and hypothalamic deafferentation (Molina et al., 1986a) (see Fig. 2) and by passive immunization against GnRH (Esbenshade \& Britt, 1985; Esbenshade et al., 1986) and after feeding the centrally active compound, methallibure (synonyms = AIMAX or ICI 33828; Kesner et al.; 1987) (Fig. 3), indicating the existence of a 'pulse generator' within the CNS. Secretion of FSH was also abolished after passive immunization against GnRH (Esbenshade \& Britt, 1985; Esbenshade et al., 1986), but not after hypophysial stalk section (Kraeling et al., 1987). Progesterone (Estienne et al., 1989) and cortisol (unpublished) failed to suppress LH secretion in response to pulsatile administration of GnRH in hypophysial stalk-sectioned gilts, indicating that the well documented negative feedback action of these steroids on pulsatile LH secretion in pigs occurs at the CNS rather than at the pituitary gland.

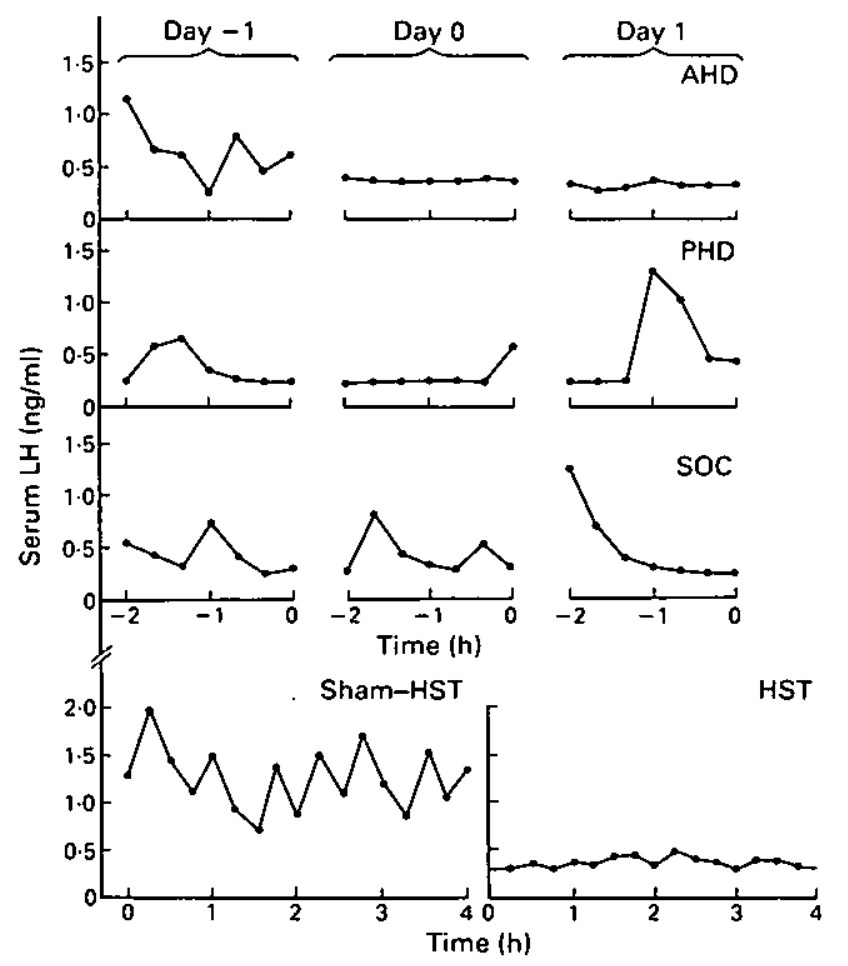

Fig. 2. Serum LH concentrations in representative ovariectomized gilts before and after anterior hypothalamic deafferentation (AHD), posterior hypothalamic deafferentation (PHD) or complete hypothalamic deafferentation (CHD) (from Molina et al. (1986a)) and after sham hypophysial stalk transection (Sham-HST) or HST (R. R. Kraeling, unpublished observations). 


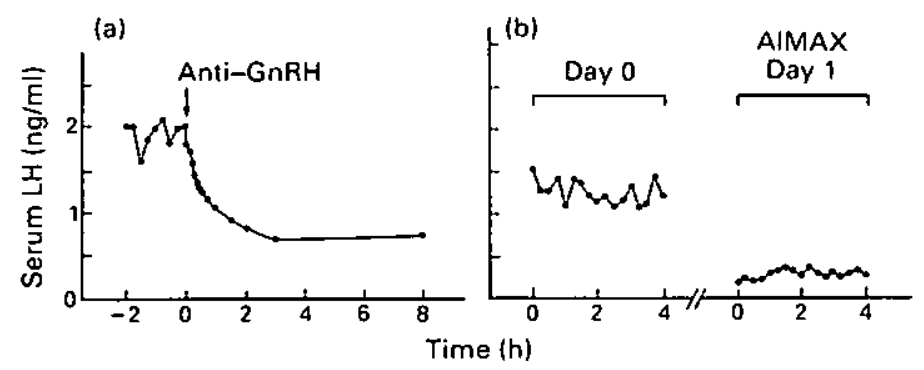

Fig. 3. Serum LH concentrations in gilts before and after treatment with (a) gonadotrophinreleasing hormone antiserum (anti-GnRH; $N=4$ ) (from Esbenshade et al., 1986)) or (b) $\operatorname{AIMAX}(\mathrm{N}=3)$ (from Kesner et al., 1987).

\section{Gonadotrophin 'surge generator'}

It is generally accepted that the increasing serum concentration of oestradiol secreted by developing preovulatory follicles stimulates the preovulatory surge of gonadotrophins. Acute or chronic exogenous oestradiol caused immediate suppression of serum LH concentrations followed by a sustained, preovulatory-like surge of LH at 48-72 h after injection in gilts (Fig. 4) and post-partum sows (Elsaesser, 1982; Dial et al., 1983; Britt et al., 1985; Christenson et al., 1985; Kesner et al., 1987). Oestrogen inhibits LH secretion, first by suppressing gonadotroph responsiveness to $\mathrm{GnRH}$ and, perhaps, CNS production of GnRH for 12-24 h followed thereafter by suppression of CNS production of GnRH (Cox \& Britt, 1982; Kesner et al., 1987, 1989a; J. H. Britt \& K. L. Esbenshade, unpublished observations).

Signals from the CNS apparently are required to elicit the preovulatory gonadotrophin surge in the pig as Parvizi et al. (1976) blocked or delayed the LH surge in the majority of pigs anaesthetized with pentobarbitone sodium during pro-oestrus. Also, placement of lesions in the medial basal anterior hypothalamus of gilts blocked ovulation, resulting in polyfollicular and cystic ovaries without formation of corpora lutea (Docke \& Busch, 1974). In addition, the preovulatory-like LH surge induced by oestradiol in ovariectomized gilts was blocked by $\mathrm{GnRH}$ antiserum (Britt $e t$ al., 1987; J. H. Britt \& K. L. Esbenshade, unpublished observations), after hypophysial stalk section (Kesner et al., 1989a) and after feeding methallibure (Kesner et al., 1987) (Fig. 4).

Oestradiol (Day 0) failed to induce an LH surge in gilts with hypophysial stalk section and given $1 \mu \mathrm{g} \mathrm{GnRH} / 45 \mathrm{~min}$ (which is adequate to re-establish pulsatile LH secretion in such gilts) on Day -5 to Day 0, Day -5 to Day 4, or Day -5 to Day 0 and then Day 2 to Day 4 (Kesner et al., 1989a). Oestradiol also failed to induce an LH surge in gilts passively immunized against GnRH and given pulsatile GnRH analogue on Days 0 to 4 (J. H. Britt \& K. L. Esbenshade, unpublished observations) or in gilts given pulsatile GnRH on Days 0 to 2 (Kesner et al., 1989b). However, oestradiol and pulsatile GnRH analogue on Day 2.5 to Day 4 in gilts passively immunized against GnRH stimulated an LH surge similar to that in oestradiol-primed controls. These latter results (Fig. 5) and those of Cox \& Britt (1982) indicate that suppression of LH secretion before the LH surge is required for accumulation of adequate stores of LH in the anterior pituitary gland for later surge release. Emergence of the $\mathrm{LH}$ surge is probably, a manifestation of resumed endogenous GnRH secretion. Thus, unlike primates in which oestradiol needs only to stimulate the anterior pituitary gland to induce the preovulatory LH surge, and unlike sheep and cows in which oestradiol stimulates the LH surge by acting on both the CNS and the anterior pituitary (Kesner, 1988), oestradiol apparently stimulates the preovulatory LH surge in pigs by acting primarily on the CNS. 


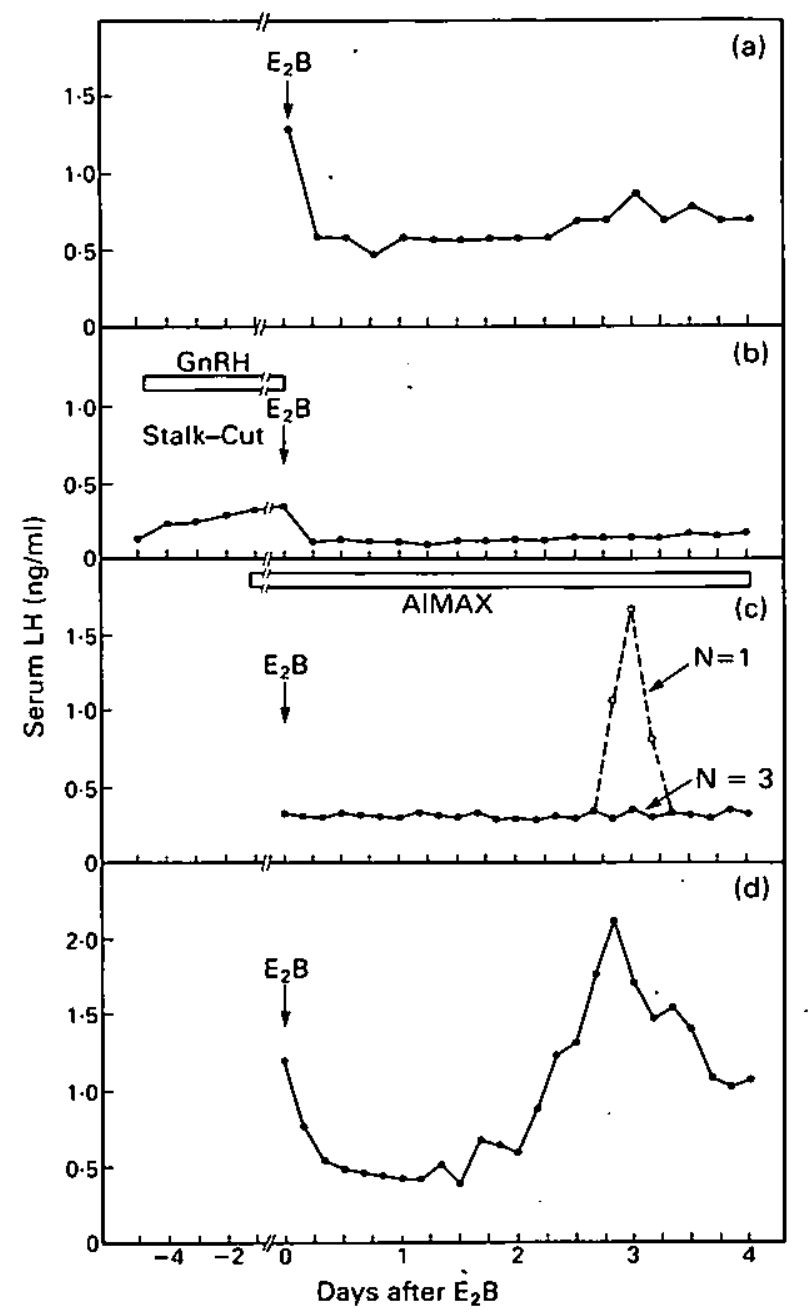

Fig. 4. Serum LH concentrations in gilts injected i.m. with oestradiol benzoate $\left(E_{2} B\right)$. Gonadotrophin-releasing hormone (GnRH) secretion was blocked by: (a) anti-GnRH (N = 7; J. H. Britt \& K. L.. Esbenshade, unpublished observations), (b) hypophysial stalk transection ( $\mathrm{N}=6$; Kesner et al., 1989a), (c) AlMAX treatment (Kesner et al., 1987). Gilts in (d) were controls (N = 4; Kesner et al., 1987).

\section{Brain neurotransmitter regulation of FSH and LH}

The role of various neurotransmitters in controlling FSH and LH secretion has'not been established for the pig. As noted previously (Fig. 2), anterior and complete hypothalamic deafferentation in ovariectomized, prepubertal gilts abolished pulsatile $\mathrm{LH}$ secretion and significantly reduced basal serum concentrations of $\mathrm{LH}$, whereas posterior hypothalamic deafferentation and sham operation failed to alter these indices of LH secretion (Molina et al., 1986a). Molina et al. (1986a) concluded that the neural stimuli required for the episodic release of $\mathrm{LH}$ in the pig originate in or traverse the anterior hypothalamic area. If one assumes that pigs are similar to several other species in that noradrenergic nerve tracts, which might influence $\mathrm{GnRH}$ perikarya found in the preoptic area and the anterior hypothalamic area by Kineman et al. (1988), are extrinsic to the hypothalamus (Weiner et al., 1988), then noradrenergic stimuli were possibly disrupted by anterior and complete 


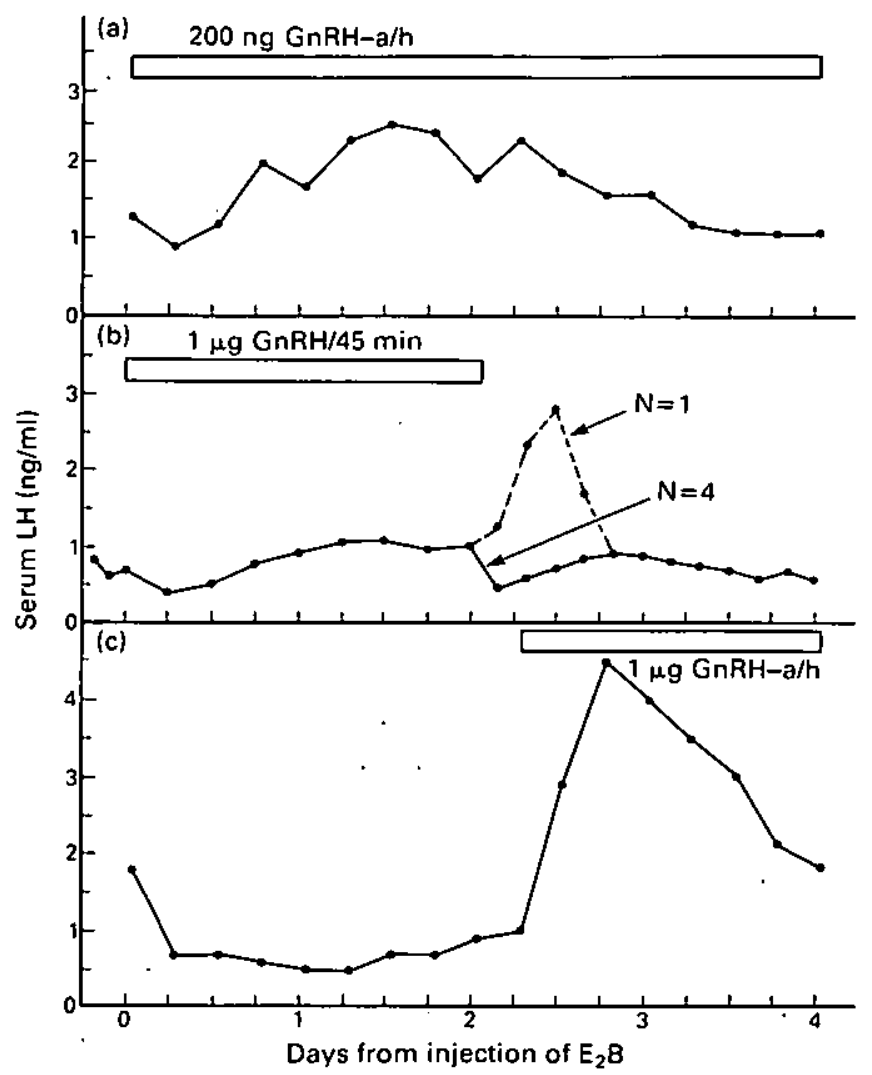

Fig. 5. Serum LH concentrations in gilts injected i.m. with oestradiol benzoate $\left(E_{2} B\right)$. Bar represents time of i.v. administration of $\mathrm{GnRH}$. Gilts in $(\mathrm{a}, \mathrm{N}=4)$ and $(\mathrm{c}, \mathrm{N}=11)$ were passively immunized against GnRH (from J. H. Britt \& K. L. Esbenshade, unpublished observations). (b) From Kesner et al. (1989b). GnRH-a $=\mathrm{GnRH}$ analogue.

hypothalamic deafferentation. The noradrenaline synthesis inhibitor, diethyldithiocarbamate (DDC), decreased LH secretion in ovariectomized prepubertal gilts (M. J. Estienne, C. R. Barb, G. B. Rampacek \& R. R. Kraeling, unpublished observations; Fig. 6). In addition, there is indirect evidence that catecholamines are involved in the pulsatile LH secretion mechanism in pigs (Kesner $e t$ al., 1987). Pulsatile LH secretion was completely blocked (Fig. 3) and pulsatile FSH secretion was severely suppressed in ovariectomized gilts treated with methallibure which, like DDC, is a carbamate compound derived from hydrazine. Previous reports of Ellendorff \& Parvizi (1982) and Parvizi \& Ellendorff (1982) demonstrated that the LH response to CNS administration of noradrenaline in adult, gonadectomized Göttingen miniature pigs was dependent on dose and site of placement.

The limited data available concerning the role of dopamine in the regulation of gonadotrophin secretion in pigs is controversial. Kraeling et al. (1982) showed that the dopamine agonist, bromocriptine, decreased serum LH concentrations in lactating sows but not in ovariectomized gilts. However, Bevers it al. (1983) reported that bromocriptine increased LH secretion in lactating sows. Dusza et al. (1983) failed to alter LH secretion with bromocriptine on Days 14 and 16 of the oestrous cycle in gilts. We are unaware of any studies of noradrenergic regulation of gonadotrophin secretion in pigs in other physiological states, such as various stages of the oestrous cycle, during the preovulatory gonadotrophin surge or during suckling in lactating sows. However, the LH surge induced by oestradiol was completely abolished (Fig. 4) and the FSH surge suppressed in ovariectomized gilts fed methallibure (Kesner et al., 1987). The action of methallibure was relatively 


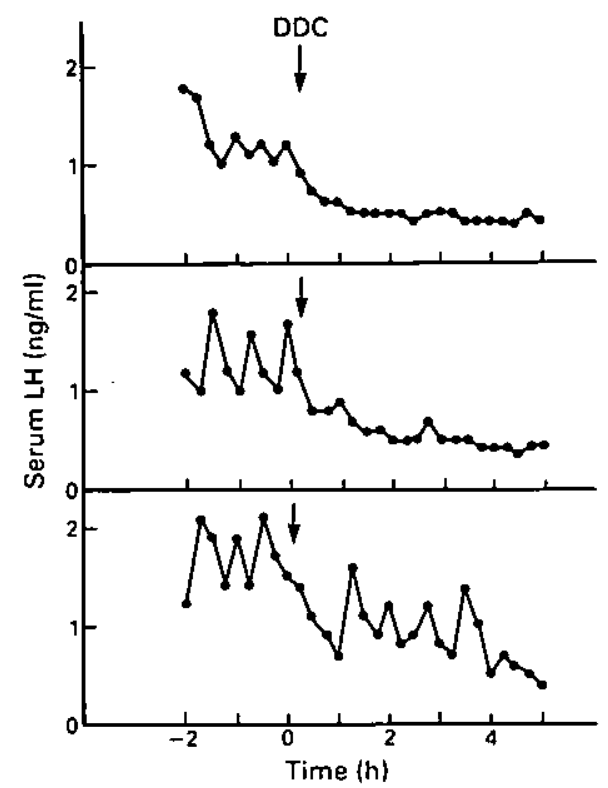

Fig. 6. Serum LH concentrations in representative ovariectomized gilts before and after diethyldithiocarbamate (DDC) i.v. (M. J. Estienne, C. R. Barb, G. B. Rampacek \& R. R. Kraeling, unpublished observations).

specific since serum concentrations of prolactin, growth hormone, thyroid hormones or cortisol were not altered. In addition, pituitary responsiveness to $\mathrm{GnRH}$ was not compromised.

\section{Brain neurotransmitter regulation of prolactin secretion}

Changes in serum prolactin concentrations after hypophysial stalk transection indicate that prolactin secretion is primarily under tonic inhibition by the CNS in pigs. Anderson et al. (1982) reported that serum prolactin concentrations remained significantly elevated in hypophysial stalktransectioned (HST) gilts compared to sham-operated gilts for up to $192 \mathrm{~h}$ after surgery. Although Kraeling et al. (1986) and Kraeling \& Rampacek (1986) reported that serum prolactin concentrations were similar for HST and sham-HST gilts at 9-10 weeks after surgery, Kraeling et al. (1988) and Kesner et al. (1989a) subsequently found that serum prolactin concentrations were significantly greater in HST gilts than in sham-HST gilts 8-28 weeks after surgery.

Numerous studies indicate that dopanine is a hypothalamic prolactin-inhibiting factor in the pig. Bromocriptine suppressed prolactin secretion in gilts during the oestrous cycle, in periparturient and lactating sows, and in ovariectomized gilts (Whitacre \& Threlfall, 1981; Kraeling et al., 1982; Taverne et al., 1982; Bevers et al., 1983; Dusza et al., 1983; Smith \& Wagner, 1985). Bromocriptine also reduced basal serum prolactin concentrations in HST gilts to levels equivalent to those in intact control gilts and blocked the prolactin response to TRH in HST and control gilts (Fig: 7) (Kraeling et al., 1988). In contrast, the dopamine antagonist, haloperidol, stimulated prolactin secretion in gilts during the oestrous cycle and in lactating sows (Kendall et al., 1983). Complete hypothalamic deafferentation in gilts failed to alter serum prolactin concentrations (Molina $e t$ al., 1986b). Therefore, neural pathways within the hypothalamus alone maintain tonic inhibition of prolactin secretion in pigs. These results are consistent with the concept that dopaminergic pathways tonically inhibit prolactin secretion in pigs if one assumes that, as in several other species, dopaminergic neurones involved in the regulation of prolactin secretion are intrinsic to the hypothalamus (Weiner et al., 1988). 


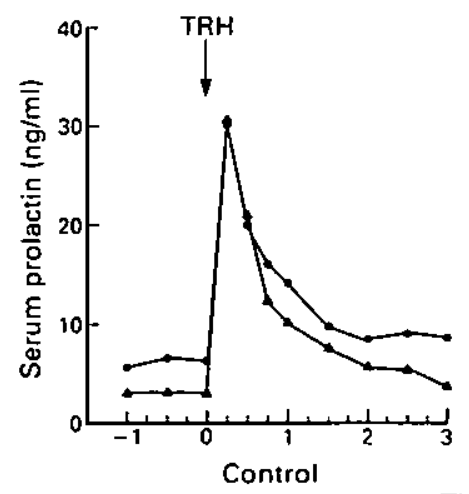

Time (h)

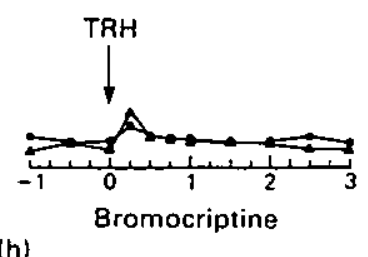

Fig. 7. Prolactin response to thyroid-stimulating hormone relcasing hormone (TRH) before and after bromocriptine treatment in hypophysial stalk-transected (HST; $N=6$ ) and intact $(\mathrm{N}=4)$ gilts (Kraeling et al., 1988).

Oestradiol stimulated basal prolactin secretion and prolactin response to TRH in HST gilts (Kraeling \& Rampacek, 1986). Therefore, at least part of the mechanism involved in stimulating the perioestrous surge of prolactin (Brinkley, 1981) is a direct action of oestrogen on the anterior pituitary gland.

\section{Endogenous opioid peptides}

The EOPs, which are naturally occurring ligands for receptors that also bind opiate drugs, are distributed in various loci throughout the brain. Endorphins, enkephalins and dynorphins are three families of EOPs formed from post-translational processing of their respective precursor proteins (Weiner et al., 1988). The EOPs and their respective antagonists generally infuence LH, FSH and prolactin secretion under appropriate conditions in all species studied to date.

\section{EOP modulation of gonadotrophin secretion}

There are few reports on the effects of EOP agonists and antagonists on gonadotrophin secretion in pigs. Peripheral administration of morphine inhibited LH secretion in post-partum sows (Armstrong et al., 1988b) and ovariectomized gilts (J. S. Kesner, M. J. Estienne, C. R. Barb, R. R. Kraeling \& G. B. Rampacek, unpublished observations), and intracerebroventricular administration of morphine suppressed LH but the FSH response was inconsistent in ovariectomized gilts (Estienne et al., 1990; Barb et al., 1989). In ovariectomized miniature pigs, microinjection of $\beta$-endorphin into the amygdala, but not the hypothalamus, inhibited LH secretion (Parvizi \& Ellendorff, 1980).

The EOPs have been implicated in regulation of LH and FSH secretion in sexually mature gilts and post-partum sows. In sexually mature gilts, the EOP antagonist, naloxone, enhanced LH secretion during the luteal phase but not during the early or late follicular phase of the oestrous cycle (Barb et al., 1985, 1986a). In addition, naloxone failed to increase LH secretion in mature ovariectomized gilts unless progesterone was administered (Barb et al., 1988). Secretion of FSH was unaffected by naloxone at all stages of the oestrous cycle studied and in ovariectomized and in ovariectomized progesterone-treated gilts (C. R. Barb, R. R. Kraeling \& G. B. Rampacek, unpublished observations). These results provide evidence that, in pigs, EOPs are part of a progesteronedependent negative feedback system controlling LH secretion, and are compatible with results of Estienne et al. (1989) who demonstrated that progesterone failed to reduce pituitary responsiveness to pulsatile administration of GnRH in HST gilts. 
In intact and ovariectomized, progesterone-treated prepubertal gilts, blockade of EOP receptors by naloxone failed to alter LH and FSH secretion (Barb et al., 1988; C. R. Barb, G. B. Rampacek \& R. R. Kraeling, unpublished observations). However, LH secretion increased when gilts were ovariectomized prepubertally and treated with progesterone and naloxone at a chronological age when puberty occurred in intact contemporary gilts (Barb et al., 1988). In contrast, naloxone increased LH secretion in immature castrated male pigs implanted with testosterone, but not in intact or castrated animals (Patchev et al., 1987; Trudeau et al., 1988). We conclude that development of EOP modulation of LH secretion in prepubertal gilts is a brain maturational process which may require progesterone for activation but is independent of the ovaries, while Patchev et al. (1987) suggested that, in immature male pigs, adult serum concentrations of testosterone are required for activation of the EOP neuronal system. These results in the prepubertal gilt may reflect the absence of a functional link between EOP neurones and the $\mathrm{GnRH}$ secretory system. However, EOP receptors were functionally coupled to the $\mathrm{GnRH}$ secretory system since intracerebroventricular administration of morphine to ovariectomized prepubertal gilts suppressed LH secretion in a subsequent study (Barb et al., 1989). However, intravenous morphine failed to alter LH secretion in miniature male pigs (Trudeau et al., 1988). Perhaps, in prepubertal gilts, EOP neurones which inhibit LH secretion in mature female pigs are either not anatomically coupled to the GnRH secretory system or are not physiologically activated until puberty occurs. Similar findings were reported for infantile male rats (Valenca \& Negro-Vilar, 1986).

Naloxone increased LH (Barb et al., 1986b; Mattioli et al., 1986) and FSH (Barb et al., 1987) secretion in lactating sows. The response to naloxone was no longer demonstrable after weaning (Barb et al., 1986b, 1987). Elevation of gonadotrophin secretion, which occurs when suckling is prevented, possibly masked a response to naloxone. Like transient weaning, naloxone infusion increased LH pulse frequency (Armstrong et al., 1988a). In addition, acute morphine treatment suppressed the stimulatory effects of transient weaning on pulsatile LH secretion, while chronic morphine treatment after weaning extended lactational anoestrus in sows (Armstrong et al., 1988b). We suggest that during lactation EOPs act within the pig hypothalamus to reduce GnRH release and thereby inhibit $\mathrm{LH}$ secretion.

\section{Immunocytochemistry of GnRH and pro-opiomelanocortin in the forebrain}

Kineman et al. (1988) examined GnRH-immunostained perikarya and processes in the forebrains of sexually mature female pigs (Fig. 8). The greatest proportion of GnRH-immunostained perikarya were in the medial preoptic area adjacent to the organum vasculosum of the lamina terminalis. Perikarya were also scattered rostrally in the diagonal band of Broca, and within the lateral hypothalamic area, paraventricular nucleus, periventricular zone, suprachiasmatic nucleus, and medial basal hypothalamus. Immunostained processes coursed along the ventral surface to the median eminence or medial and ventral to the third ventricular wall to the median eminence. Extrahypothalamic processes were found in the lateral septal area, stria terminalis, central thalamus and the habenular nucleus. GnRH-immunostained neurones were unipolar, bipolar and multipolar. Close associations between individual neurones were observed, and this may be indicative of coordinated interaction between GnRH neurones. Perhaps pulsatile LH secretion was abolished after anterior and complete hypothalamic deafferentation in gilts (Molina et al., 1986a) because fibres from these GnRH perikarya were severed.

Proopiomelanocortin (POMC; $\beta$-endorphin precursor)-immunoreactive perikarya are located within the arcuate area (Kineman et al., 1989). POMC-immunoreactive fibres project to sites of GnRH perikarya in the medial basal hypothalamus, periventricular zone and preoptic area (Fig. 9). These neurones were also unipolar, bipolar and multipolar. POMC-GnRH-immunoreactive fibres also overlap in areas of the median eminence. The immunocytochemical localization of other EOPs has not yet been examined in pigs. 


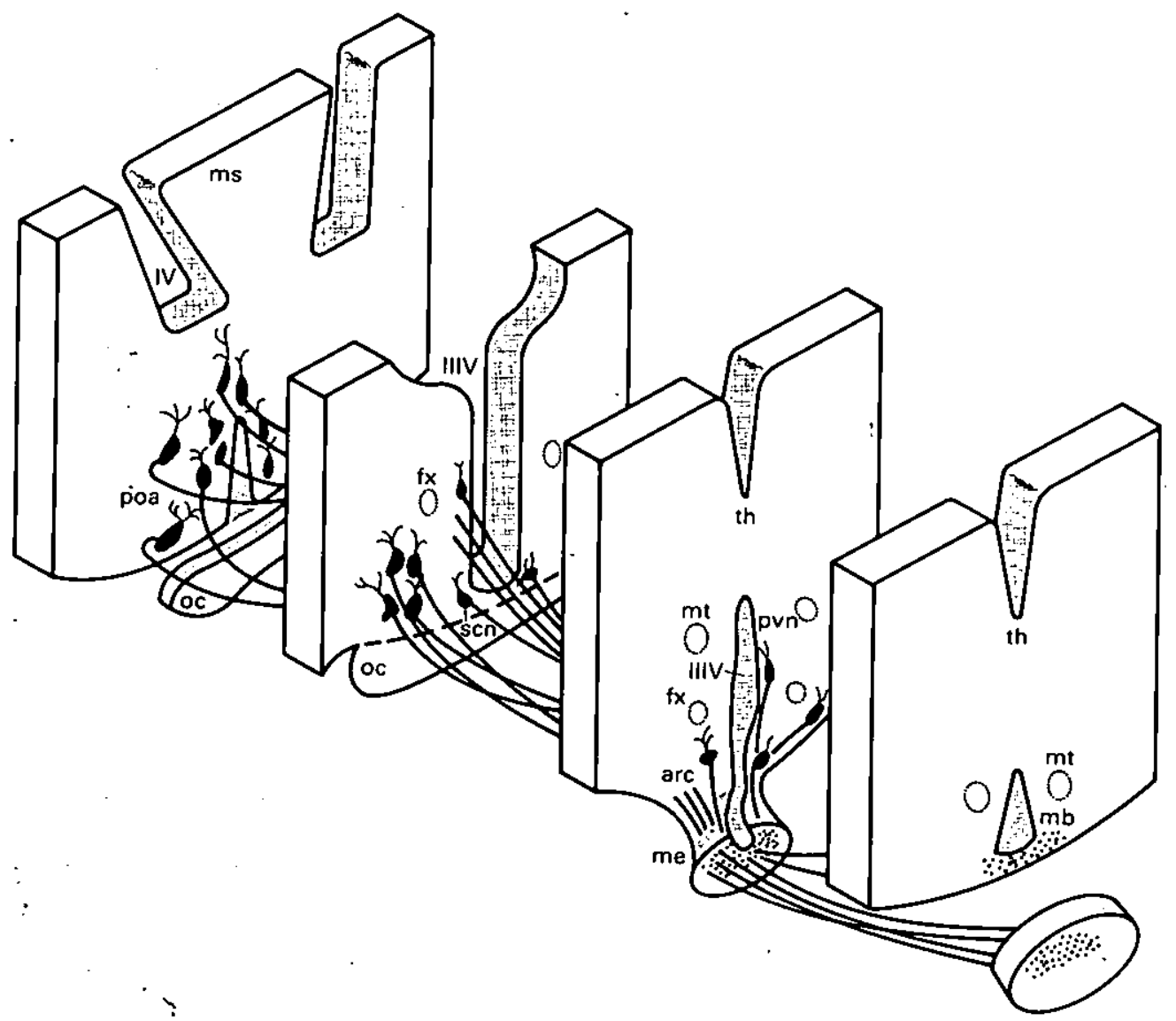

Fig. 8. Distribution of gonadotrophin-releasing hormone perikarya and fibres in the forebrain of the pig: arc = arcuate nucleus; $f x=$ fornix; $l v=$ tateral ventricle; $m b=$ mamillary body; me = median eminence; $\mathrm{ms}=$ medial septum; $\mathrm{mt}=$ mamillo-thalamic tract; oc =optic chiasma; pvn = paraventricular nucleus; poa = preoptic area; $\operatorname{sen}=$ suprachiasmatic nucleus; th $=$ thalamus; IIIV $=$ third ventricle.

Tyrosine hydroxylase and dopamine $\beta$-hydroxylase, enzymes involved in catecholamine synthesis (Weiner et al., 1988), have been localized in the medial basal hypothalamus of pigs (Leshin et al., 1989). Therefore, anatomically, catecholaminergic neurones, the POMC system and GnRH secreting neurones are well positioned to interact within the hypothalamus.

\section{EOP modulation of prolactin secretion}

The EOPs have been implicated in the control of prolactin secretion in several species (Weiner et al., 1988). Serum prolactin concentrations increased markedly after intracerebroventricular administration of morphine in ovariectomised mature and prepubertal gilts (Estienne et al., 1990; C. R. Barb, R. D. Kineman, J. S. Kesner, G. B. Rampacek \& R. R. Kraeling, unpublished observations) and after intravenous injection in immature male pigs (Trudeau et al., 1988). The circulating steroid hormone milieu influenced EOP modulation of prolactin secretion in gilts (Barb et al., 1986a). Naloxone increased serum prolactin concentrations during the luteal phase, but not during the follicular phase, of the oestrous cycle or after ovariectomy. 

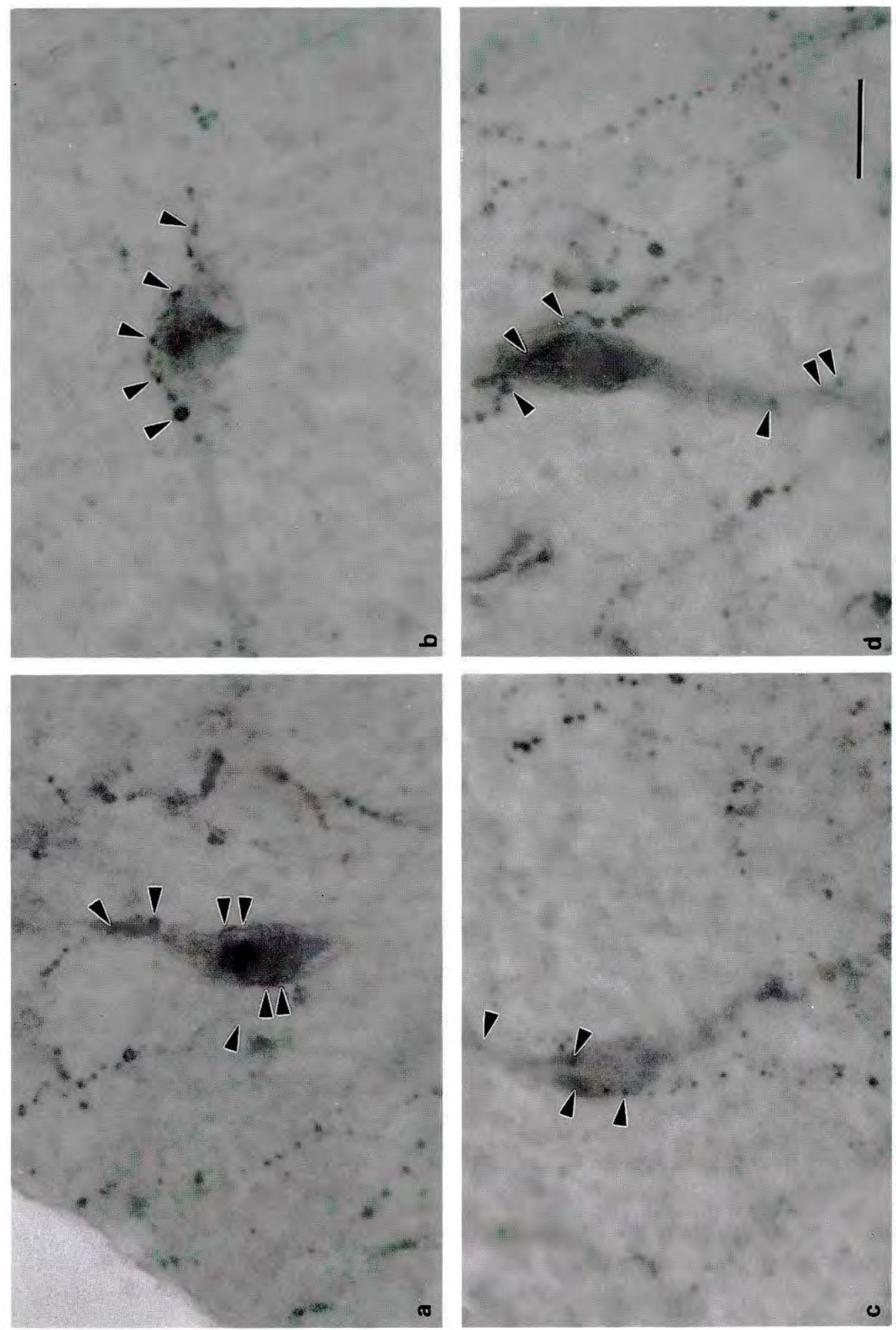

苞 बें 记夆 D्त उु है चु ङू 实 ส के के क⿺ 过 읨. 的 एँ

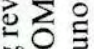
on: 至吉 $\exists$ 年 $\Xi$ 无

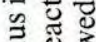
है 픙

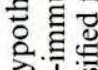
ฮ่ 芯 증흥 7 요 实 0 ( ) $=8$ v $\Xi$ 西 인지 현 폰유 के त्रें 可 힝 要 공 등 氜焉 ค응 $\circ$ 이 인 
Table 2. Influence of intracerebroventricular ${ }^{\mathrm{a}}$ (ICV) or peripheral $^{\mathrm{b}}$ administration of morphine on $\mathrm{LH}, \mathrm{FSH}$ or prolactin secretion in the ovariectomized (ovx.) prepubertal and mature gilt or post-partum sow

\begin{tabular}{lccc}
\hline Physiological state & LH & FSH & Prolactin \\
\hline Prepubertal ovx. gilt $^{\mathrm{a}}$ & $\downarrow$ & NE & $\uparrow$ \\
Mature ovx. gilt $^{\mathrm{a}, \mathrm{b}}$ & $\downarrow$ & $?$ & $\uparrow$ \\
Post-partum sow $^{\mathrm{b}}$ & $\downarrow$ & NE & $\downarrow$ \\
\hline
\end{tabular}

$\downarrow=$ Decreased; $\uparrow=$ increased.

$?=$ inconsistent response; $\mathrm{NE}=$ not examined.

Table 3. Influence of naloxone (an opioid antagonist) administration on $\mathrm{LH}, \mathrm{FSH}$ and prolactin secretion in the pig during different physiological states

\begin{tabular}{lccc}
\hline Physiological state & LH & FSH & Prolactin \\
\hline $\begin{array}{l}\text { Mature gilt } \\
\text { Luteal phase }\end{array}$ & $\uparrow$ & - & $\uparrow$ \\
Follicular phase & - & - & - \\
Ovariectomized & - & - & - \\
Ovariectomized + progesterone & $\uparrow$ & - & - \\
Prepubertal gilt & & & \\
$\quad$ Intact & - & - & - \\
$\begin{array}{l}\text { Ovariectomized + progesterone } \\
\text { Ovariectomized + progesterone } \\
\text { after puberty in contemporaries }\end{array}$ & - & - & - \\
Post-partum sow & $\uparrow$ & & \\
$\quad \begin{array}{l}\text { Suckled } \\
\text { Not suckled }\end{array}$ & $\uparrow$ & $\uparrow$ & $\downarrow$ \\
\hline$\uparrow=$ Increased; $\downarrow=$ decreased; $-=$ no effect. &
\end{tabular}

The suckling-induced increase in serum prolactin concentrations in lactating sows was attenuated by either acute (Mattioli et al., 1986; Barb et al., 1987) or chronic (Armstrong et al., 1988a) naloxone treatment. Furthermore, this effect of naloxone on prolactin secretion was lost after weaning (Barb et al., 1987). These results provide evidence that EOPs are involved in the suckling-induced increase in prolactin secretion in lactating sows. The above studies demonstrate the existence of two EOP systems, one of which is steroid-dependent and inhibits prolactin secretion and the other which is suckling dependent and stimulates prolactin secretion.

Tables 2 and 3 summarize the preceding discussions of the role of EOPs in modulating gonadotrophin and prolactin secretion.

\section{Conclusions}

Evidence has been presented for the existence of an LH pulse and LH surge generator in the hypothalamus of pigs and indirect evidence for noradrenergic modulation of these centres. Prolactin secretion is also controlled by hypothalamic factors, most notably the prolactin-inhibitory factor, dopamine and the prolactin-releasing activity of TRH. Negative and positive feedback actions of ovarian steroids on LH secretion occur at the CNS rather than at the level of the pituitary gland. The action of these steroids on the LH pulse generator is a manifestation of EOP inhibition of GnRH 
secretion in the mature gilt. Similarly, during lactation the EOPs mediate the suckling-induced suppression of LH secretion. In the prepubertal gilt, EOP modulation of LH secretion is an ovarianindependent CNS maturational process, but in the infantile male pig physiological activation by testosterone is required. Prolactin secretion is modulated by two EOP systems, one of which is steroid-dependent and inhibits prolactin secretion and the other which is suckling-dependent and stimulates prolactin secretion. Lastly, dramatic and consistent FSH responses to perturbations in the neuroendocrine system may be absent because FSH is primarily under a negative feedback inhibition by inhibin.

We thank Dr Mark J. Estienne, Dr James S. Kesner, Dr Rhonda D. Kineman, Dr L. Steven Leshin and Dr George B. Rampacek, for contributing data and assistance in preparing this manuscript.

\section{References}

Anderson, L.L., Berardinelli, J.G., Malven, P.V. \& Ford, J.J. (1982) Prolactin secretion after hypophysial stalk transection in pigs. Endocrinology 111, 380-384.

Armstrong, J.D., Cox, N.M. \& Britt, J.H. (1987) Changes in the hypothalamic-hypophyseal ovarian axis of primiparous sows following weaning or pulsatile gonadotropin releasing hormone administration and weaning. Theriogenology 27, 561-570.

Armstrong, J.D., Kraeling, R.R. \& Britt, J.H. (1988a) Effects of naloxone or transient weaning on secretion of LH and prolaclin in lactating sows. J. Reprod. Fert. 83, 301-308.

Armstrong, J.D., Kraeling, R.R. \& Britt, J.H. (1988b) Morphine suppresses luteinizing hormone concentrations in transiently weaned sows and delays onset of estrus after weaning. $J$. Anim. Sci. 66, $1216-2223$.

Barb, C.R., Kraeling, R.R., Rampacek, G.B. \& Whisnant, C.S. (1985) Opioid inhibition stimulates luteinizing hormone and prolactin secretion in gilts. Dom. Anim. Endocrinology 2, 93-98.

Barb, C.R., Kraeling, R.R., Rampacek, G.B. \& Whisnant, C.S. (1986b) Opioid inhibition of luteinizing hormone secretion in the postpartum lactating sow. Biol. Reprod. 35, 368-371.

Barb, C.R., Kraeling, R.R., Rampacek, G.B. \& Whisnant, C.S. (1986a) Influence of stage of the estrous cycle on endogenous opioid modulation of luteinizing hormone, prolactin and cortisol secretion in the gilt. Biol. Reprod. 35, I162-1167.

Barb, C.R., Kraeling, R.R., Rampacek, G.B. \& Leshin, L.S. (1987) Opioid modulation of follicle stimulating hormone (FSH) and prolactin (PRL) secretion in the postpartum sow. Adv. exp. Med. Biol. 219, 647-652.

Barb, C.R., Rampacek, G.B., Kraeling, R.R., Estienne, M.J., Taras, E., Estienne, C.E. \& Whisnant, C.S. (1988) Absence of brain opioid peptide modulation of luteinizing hormone secretion in the prepubertal gilt. Biol. Reprod. 39, 603-609.

Barb, C.R., Kineman, R.D., Kesner, J.S., Rampacek, G.B., \& Kraeling, R.R. (1989) Luteinizing hormone secretion following intracerebroventricular administration of morphine in the prepuberal gilt. Life Sci. 45, 69l-696.

Bevers, M.M., Willemse, A.H. \& Kruip, A.M. (1983) The effect of Bromocriptine on luteinizing hormone levels in the lactating sow-evidence for a suppressive action by prolactin and sucking stimulus. Acra endocr., Copenh. 104, 26I-265.

Brinkley, H.J. (1981) Endocrinc signaling and female reproduction. Biol. Reprod. 24, 22-43.

Britt, J.H., Armstrong, J.D., Cox, N.M. \& Esbenshade, K.L. (1985) Control of follicular development during and after lactation in sows. J. Reprod. Fert., Suppl. $33,37-54$

Britt, J.H., Esbenshade, K.L. \& Heller, K. (1986) Responses of seasonally anestrous gilts and weaned primiparous sows to treatment with pregnant mares serum gonadotropin and altrenogest. Theriogenology 26, 697-706.

Britt, J.H., Esbenshade, K.L. \& Ziecik, A.J. (1987) Site of action of estradiol for eliciting negative and positive feedback responses of LH in pigs. Biol. Reprod. 36 (Suppl. 1), 114, abstr.

Carpenter, L.S. \& Anderson, L.L. (1985) Pulsatile infusion of luteinizing hormone-releasing hormone: effects on luteinizing hormone secretion and ovarian function in prepuberal gilts. Anim. Reprod. Sci. 9, 261-272.

Casida, L.E. (1976) Ovulation studies with particular reference to the pig. Biol. Reprod. 14, 97-107.

Christenson, R.K., Ford, J.J. \& Redmer, D.A. (1985) Maturation of ovarian follicles in the prepubertal gilt. J. Reprod. Fert., Suppl. 33, 21-36.

Colenbrander, B., Meijer, J.C., MacDonald, A.A., van der Wiel, D.F.M., Engel, B. \& de Jong, F.H. (1987) Feedback regulation of gonadotropic hormone secretion in neonatal pigs. Biol. Reprod. 36, $871-877$.

Cox, N.M. \& Britt, J.H. (1982) Effect of estradiol on hypothalamic GnRH and pituitary and serum LH and FSH in ovariectomized pigs. J. Anim. Sci. 55, 901-908.

Cox, N.M. \& Britt, J.H. (1986) Pulsatile secretion of luteinizing hormone and follicle stimulating hormone and their relationship to secretion of estradiol and onset of estrus in weaned sows. Anim. Reprod. Sci. $12,20|-2| I$.

Cox, N.M., Ramirez, J.L., Matamoros, I.A. \& Bennett, W.A. (1988) Estrogen induces estrus unaccompanied by a preovulatory surge in luteinizing hormone in suckled sows. Biol. Reprod. 38, 592-596. 
Dial, G.D., Dial, O.K., Bevier, G.W., Glenn, S.D. \& Dziuk, P.J. (1983) Estrous behavior and circadian discharge of luteinizing hormone in the prepubertal gilt in response to exogenous estrogen. Biol. Reprod. 29, 1047-1056.

Docke, F. \& Busch, W. (1974) Evidence for anterior hypothalamic control of cyclic gonadotrophin secretion in female pigs. Endokrinologie 63, 415-421.

Dusza, L., Krzymowska, H., Kotwica, G., Ziecik, A. \& Tilton, J. (1983) Prolactin, progesterone and luteinizing hormone secretion after bromocriptine (CB-154) treatment in cyclic sows. Theriogenology 20, 529-535.

Edwards, S. (1982) The endocrinology of the post-partum sow. In Control of Pig Reproduction, pp. 439-458. Eds D. J. A. Cole \& G. R. Foxcroft. Butterworths, London.

Ellendorf, F. \& Parvizi, N. (1982) The central nervous system and the control of pituitary hormone release in the pig. In Control of Pig Reproduction, pp. 179-195. Eds D. J. A. Cole \& G. R. Foxcroft. Butterworths, London.

Elsaesser, F. (1982) Endocrine control of sexual maturation in the pig and sexual differentiation of the stimulatory oestrogen feedback mechanism. In Control of Pig Reproduction, pp. 93-116. Eds D. J. A. Cole \& G. R. Foxcroft. Butterworths, London.

Esbenshade, K.L. \& Britt, J.H. (1985) Active immunization of gilts against gonadotropin-releasing hormone: effects on secretion of gonadotropin, reproductive function, and responses to agonists of gonadolropinreleasing hormone. Biol. Reprod. 33, 569-577.

Esbenshade, K.L., Vogel, M.J. \& Traywick, G.B. (1986) Clearance rate of luteinizing hormone and follicle stimulating hormone from peripheral circulation in the pig. J. Anim. Sci. 62, 1649-1653.

Estienne, M.J., Kesner, J.S., Kraeling, R.R., Rampacek, G.B. \& Barb, C.R. (1989) Luteinizing hormone secretion in hypophysial stalk-Iransected pigs given progesterone and pulsatile gonadotropin-releasing hormone. Proc. Soc. exp. Biol. Med. 190, 14-17.

Estienne, M.J., Kesner, J.S., Barb, C.R., Kraeling, R.R. Rampacek, G.B. \& Estienne, C.E. (1988) Gonadotropin and prolactin secretion following intraventricular administration of morphine in gilts. Proc. Soc. exp. Biol. Med. 93, (in press).

Foxcroft, G.R., Elsaesser, F., Stickney, K., Haynes, N.B. \& Back, H.L. (1984) Ovarian oestrogen-dependent maturation of the LH/FSH surge mechanism during prepubertal development in the gilt. $J$. Endocr. 101, $371-380$.

Foxcroft, G.R., Shaw, H.J., Hunter, M.G., Booth, P.J. \& Lancaster, R.T. (1987) Relationships between luteinizing hormone, follicle stimulating hormone and prolactin secretion and ovarian follicular development in the weaned sow. Biol. Reprod. 36, 175-191.

Goodman, R.L. (1988) Neuroendocrine control of the ovine estrous cycle. In The Physiology of Reproduction. Vol. 1, pp. 1929-1970. Eds E. Knobil, J. D. Neill, L. L. Ewing, G. S. Greenwald, C. L. Markert \& D. W. Pfaff. Raven Press, New York.

Greenwald, G.S. \& Terranova, P.F. (1988) Follicular selection and its control. In The Physiology of Reproducrion, Vol. 1, pp. 387-446. Eds E. Knobil, J. D. Neill, L. L. Ewing, G. S. Greenwald, C. L. Markerı \& D. W. Pfafr. Raven Press, New York.
Kendall, J.Z., Richards, G.E. \& Shih, L.N. (1983) Eflect of haloperidol, suckling, oxytocin and hand milking on plasma relaxin and prolaclin concentrations in cyclic and lactating pigs. J. Reprod. Fert. 69, 271-277.

Kesner, J.S. (1988) Site of action for the estradiolinduced luteinizing hormone surge in farm animals and primates. Dom. Anim, Endocr. 5, 265-28I.

Kesner, J.S., Kraeling, R.R., Rampacek, G.B. \& Johnson, B. (1987) Absence of an estradiol-induced surge of luteinizing hormone in pigs receiving unvarying pulsatile gonadotropin-releasing hormone stimulation. Endocrinology 121, 1862-1869.

Kesner, J.S., Estienne, M.J., Kraeling, R.R. \& Rampacek, G.B. (1989a) Luteinizing hormone and prolactin secretion given estradiol and pulsatile gonadotropin releasing hormone in hypophysial stalk-transected pigs. Neuroendocrinology 49, 502-508.

Kesner, J.S., Price-Taras, E.A., Kracling, R.R., Rampacek, G.B. \& Barb, C.R. (1989b) Negative fecdback as an obligatory antecedent to the estradiol-induced luteinizing hormone surge in ovariectomized pigs. Biol. Reprod. 41, 409-413.

Kineman, R.D., Leshin, L.S., Crim, J.W., Rampacek, G.B. \& Kraeling, R.R. (1988) Localization of Juteinizing hormone-releasing hormone in the forebrain of the pig. Biol. Reprod. 39, 665-672.

Kineman, R.D., Crim, J.W., Leshin, L.S., Rampacek, G.B., Kraeling, R.R. \& Barb, C.R. (1989) Localization of proopiomelanocortin (POMC) immunoreactive neurons in the forebrain of the pig. Biol. Reprod. $\mathbf{4 0 ,}$ 1119-1126.

Kirkpatrick, R.L., Lauderdale, J.W., First, N.L., Hauser, E.R. \& Casida, L.E. (1965) Ovarian and pituitary gland changes in postpartum sows treated with FSH. J. Anim. Sci. 24, 1104-I106.

Kraeling, R.R. \& Rampacek, G.B. (1986) Serum prolactin response to thyrotropin releasing hormone in cstrogen treatcd hypophysial stalk-transected gijts. Dom. Anim. Endocr. 3, 289-294.

Kraeling, R.R., Rampacek, G.B., Cox, N.M. \& Kiser, T.E. (1982) Prolaclin and luteinizing hormone secretion after bromocryptine (CB-154) treatment in lactating sows and ovariectomized gilts. J. Anim. Sci. 54, 1212-1220.

Kraeling, R.R., Barb, C.R. \& Rampacek, G.B. (1986) Ovarian response of the hypophysial stalk-transected pig to pregnant mare serum gonadotropin. Dom. Anim. Endocr. 3, 177-183.

Kraeling, R.R., Kesner, J.S., Estienne, M.J., Estienne, C.E., Barb, C.R. \& Rampacek, G.B. (1987) Follicular growth after pregnant mare serum gonadotropin (PMSG) in hypophysial stalk-transected (HST) pigs given pulsatile GnRH. Biol. Reprod. 36 (Suppl. 1). I80, absir.

Kraeling, R.R., Kesner, J.S., Estienne, M.J., Barb, C.R. \& Rampacek, G.B. (1988) Prolactin secretion after bromocriptine in the hypophysial stalk-transected gilt. Proc. $/ / \mathrm{th} \mathrm{lm}$. Congr. Anim. Reprod. \& A.I., Dublin 1, 9.

Leshin, L.S., Kineman, R.D., Barb, C.R., Kiser, T.E., Rampacek, G.B. \& Kraeling, R.R. (1989) Tyrosine hydroxylase (TH) immunoreactive neurons in the hypothalamus of cattle and pigs. Proc. $19 \mathrm{th} \mathrm{A}$. Mtg Soc. Neuroscience 15, 587, abstr. 
Lutz, J.B., Rampacek, G.B., Kraeling, R.R. \& Pinkert, C.A. (1984) Serum luteinizing hormone and estrogen profiles before puberty in the gilt. J. Anim. Sci. 58, 686-69l.

Lutz, J.B., Rampacek, G.B. \& Kraeling, R.R. (1985) Induction of ovulation in the prepuberal gilt by pulsatile administration of gonadotropin releasing hormone. Dom. Anim. Endocr. 2, 61-65.

Mattioli, M., Conte, F., Galeati, G. \& Seren, E. (1986) Effect of naloxone on plasma concentrations of prolactin and LH in lactating sows. J. Reprod. Fert. 76, 167-173.

Molina, J.R., Hard, D.L. \& Anderson, L.L. (1986a) Hypothalamic deafrerentation and luteinizing hormone-releasing hormone effects on secretion of luteinizing hormone in prepubertal pigs. Biol. Reprod. 35, 439-446.

Molina, J.R., Klindt, J., Ford, J.J. \& Anderson, L.L. (1986b) Growth Hormone and prolactin secretion after hypothalamic deafferentation in pigs. Proc. Soc. exp. Biol. Med. 183, 163-168.

Page, R.B. (1988) The anatomy of the hypothalamohypophyseal complex. In The Physiology of Reproduction, Vol. 1, pp. 1161-1234. Eds E. Knobil, J. D. Neill, L. L. Ewing. G. S. Greenwald, C. L. Markert \& D. W. Pfaff. Raven Press, New York.

Parvizi, N. \& Ellendorff, F. (1980) $\beta$-endorphin alters luteinizing hormone secretion via the amygdala but not the hypothalamus. Nature, Lond. 286, 812-813.

Parvizi, N. \& Ellendorf, F. (1982) Further evidence on dual effects of norepinephrine on LH secretion. Neuroendocrinology 35, 48-55.

Parvizi, N., Elsaesser, F., Smidt, D. \& Ellendorfi, F. (1976) Plasma luteinizing hormone and progesterone in the adult female pig during the oestrous cycle, late pregnancy and lactation, and after ovariectomy and pentobarbitone treatment. J. Endocr. 69, 193-203.
Patchev, V., Parvizi, N. \& Ellendorf, F. (1987) Naloxone effects on lutcinizing hormone secretion in immature male pigs: an androgen independent process. Neuroscience 22 (Suppl. 1), 5156 , abstr.

Shaw, H.J. \& Foxcroft, G.R. (1985) Relationships between LH, FSH and prolactin secretion and reproductive activity in the weaned sow. $J$. Reprod. Fert. 75, 17-28.

Smith, B.B. \& Wagner, W.C. (1985) Effect of dopamine agonist or antagonist, TRH, stress and piglet removal on plasma prolactin concentrations in lactating gilts. Theriogenology 23, 283-296.

Taverne, M., Bevers, M., Bradshaw, J.M.C., Dieleman, S.J., Willemse, A.H. \& Porter, D.C. (1982) Plasma concentrations of prolactin, progesterone, rclaxin and oestradiol- $17 \beta$ in sows treated with progesterone, bromocriptinc or indomethacin during late pregnancy. J. Reprod. Fert. 65, 85-96.

Trudeau, V.L., Meijer, J.C., van de Wiel, D.F.M., Bevers, M.M. \& Erkens, J.H.F. (1988) Effects of morphine and naloxone on plasma levels of LH, FSH, prolactin and growth hormone in the immature male pig. $J$. Endocr. 119, 501-508.

Valenca, M.M. \& Negro-Vilar, A. (1986) Lack of a functional coupling between endogenous opiate systems and LHRH neurons during the infantile period in the male rat. Neuroendocrinology Letters 8, 165-171.

Weiner, R.1., Findell, P.R. \& Kordon, C. (1988) Role of classic and peptide neuromediators in the neuroendocrine regulation of $\mathrm{LH}$ and prolactin. In The Physiology of Reproduction, Vol. I, pp. 1235-1282. Eds E. Knobil, J. D. Neill, L. L. Ewing, G. S. Greenwald, C. L. Markert \&nD: W. Pfaft. Raven Press, New York.

Whitacre, M.D. \& Threlfall, W. (1981) Effects of ergocryptine on plasma prolactin, luteinizing hormone and progesterone in the periparturient sow. $A m$. J. vet. Res. 42, 1538-1541. 